Article

\title{
Efficient Degradation of Norfloxacin and Simultaneous Electricity Generation in a Persulfate-Photocatalytic Fuel Cell System
}

\author{
Jiawen $\mathrm{Li}^{1}$, Ruizhen $\mathrm{Li}^{1}{ }^{1} * \mathbb{D}$, Luomei Zou ${ }^{1}$ and Xingyong Liu ${ }^{2}$ \\ 1 School of Chemistry and Environmental Engineering, Sichuan University of Science and Engineering, \\ Zigong 64300, China; jarvan966848@163.com (J.L.); Zlmei517@163.com (L.Z.) \\ 2 School of Chemical Engineering, Sichuan University of Science and Engineering, Zigong 64300, China; \\ liuxy@suse.edu.cn \\ * Correspondence: liruizhen007@163.com; Tel.: +86-135-0817-7897
}

Received: 26 September 2019; Accepted: 3 October 2019; Published: 8 October 2019

\begin{abstract}
Photocatalytic fuel cell (PFC) has been verified to be a promising technique to treat organic matter and recover energy synchronously. Sulfate radicals $\left(\mathrm{SO}_{4}{ }^{-}\right)$, as a strong oxidant, have obvious advantages in the degradation of refractory pollutants compared with hydroxyl radicals $(\cdot \mathrm{OH})$, which is the dominant radical in PFC. This study reports a coupling method of PFC and persulfate (PS) activation to promote the degradation of antibiotic norfloxacin (NOR) and simultaneous electricity generation. The added PS as an electron acceptor could be activated by photoelectric effects to produce $\mathrm{SO}_{4}{ }^{-}$at the electrodes-electrolyte interface. In the solution, PS as supporting electrolyte could accelerate the electron transfer and also be activated by ultraviolet (UV) light irradiation, which could extend the radical oxidation reaction to the whole solution and improve the PFC performance. The performance comparison among different systems indicated the excellent synergistic effect of PFC and PS activation for improving NOR degradation and electricity generation. The effects of influencing factors including initial $\mathrm{pH}$, PS concentration, and initial NOR concentration on the degradation of NOR were investigated extensively to find out the optimal conditions. Moreover, according to the results of radical capture experiments, the significantly contribution of both $\mathrm{SO}_{4} .^{-}$ and $\cdot \mathrm{OH}$ to the degradation of NOR was demonstrated and a tentative function mechanism for the NOR degradation in the proposed system was provided. Finally, total organic carbon and real wastewater treatment confirmed the high mineralization and practical applicability of the proposed PFC/PS system.
\end{abstract}

Keywords: photocatalytic fuel cell; persulfate activation; norfloxacin; degradation; electricity generation

\section{Introduction}

With the massive consumption of fossil fuels including coal, petroleum, and natural gas, conventional energy is facing a dry up. Thus, development and utilization of abundant, clean, and renewable energy sources has become a present hot research issue. The exploitation of solar energy has been extensively studied to realize $\mathrm{H}_{2}$, methyl alcohol, methane, and electric energy production by using photocatalytic water splitting [1], photocatalytic reduction of carbon dioxide [2-4], and photovoltaic solar cell [5]. Compared to hydrogen and other hydrocarbons, the transport and the use of electric energy are more secure and convenient undoubtedly.

On the other hand, environmental pollution, especially pollution of organic contaminants caused by urbanization and industrialization, is another serious threat to human health and development. In fact, 
organic compounds, particularly refractory organics, contain rich chemical energy [6]. Nevertheless, the traditional treatment methods for these organic contaminants such as biological, physical, and chemical processes only focus on elimination of pollutants, while ignoring the recovery of energy stored in them $[7,8]$.

Photocatalytic fuel cell (PFC) was regarded as a rational method for converting both solar energy in light and chemical energy in organic pollutants into electricity and simultaneously degrading organic pollutants during photocatalytic oxidation process. It is a promising technology to address energy crisis and control water pollution. This is unlike microbial fuel cells (MFC) that require strict bacteria cultivation conditions, specifically substrates, which have complicated electron transfer process and temperature requirements [9]. PFC, as an attractive technology, has attracted considerable attention due to its simple operation and direct charge-transfer. In a PFC system, almost all kinds of organic compounds, even at trace levels, can be decomposed by free radicals (mainly hydroxyl radicals $(\cdot \mathrm{OH})$ ) and photogenerated holes on the surface of photoanodes under light illumination. The photogenerated electron synchronously can transfer to the cathode through the external circuit to produce electric power. In recent years, many efforts have been devoted to improve the performance of PFC systems by some effective measures including developing visible-light-responsive materials as photoelectrodes to expand the light absorption range and enhance light absorption (such as $\mathrm{BiVO}_{4} / \mathrm{WO}_{3} / \mathrm{W}, \mathrm{CdS}-\mathrm{TiO}_{2}$, and $\mathrm{BiOCl} / \mathrm{Ti}$ ) [10-12], and using semiconductor photocathodes instead of expensive $\mathrm{Pt}$ cathode to improve the photogenerated electron-hole pairs separation efficiency and reduce the cost of PFC system [13-15]. Although, these research efforts previously reported have been demonstrated to have a degree of success, the performance of the PFC system is still less than satisfactory because PFC system has some significant intrinsic drawbacks. For instance, high recombination rate of photogenerated electron-hole pairs on the surface and inside the semiconductors influences the PFC performance of photoelectrodes. Additionally, photocatalytic redox reactions among free radicals, contaminants, and water principally occur at the single anode or cathode electrodes-electrolyte interface [16]. Nevertheless, the electrodes-electrolyte interface area depends on the surface area of the electrodes which cannot be infinitely increased. Therefore, extending the radical reactions from electrodes-electrolyte interface to the whole electrolyte solution is a feasible way to improve the performance of PFC system. Zhao et al. [17] established a novel Fenton-PFC system using $\mathrm{TiO}_{2}$ nanotube arrays as a photoanode and adding ferrous ions to induce photoelectric Fenton reaction and expand the radical reaction for organic pollutants degradation from the surface of electrodes to the whole solution system. In this Fenton-PFC system, the degradation rate of several refractory organics had been increased. Moreover, the electricity generation had been demonstrated larger than the traditional PFC [17].

Activated persulfate oxidation as a recently emerging advanced oxidation process (AOP) for organic pollutants degradation have attracted many researchers' interest due to its unique advantages. First of all, persulfate $\left(\mathrm{S}_{2} \mathrm{O}_{8}{ }^{2-}, \mathrm{PS}\right)$ itself is a strong oxidant that exhibits both the properties of reactive (for example, hydrogen peroxide and ozone) and persistent (for instance, permanganate) oxidants [18]. PS has a high standard oxidation potential $\left(\mathrm{E}^{0}\right)$ of $2.01 \mathrm{~V}$. In addition, the decomposition of PS via thermal, photochemical, or metal ions activation can form reactive radical intermediates, namely sulfate free radical $\left(\mathrm{SO}_{4} \cdot^{-}\right)$, with a $\mathrm{E}^{0}$ value varied between +2.5 and $+3.1 \mathrm{~V}$ versus $\mathrm{NHE}$ which is higher than hydroxyl radicals $(\cdot \mathrm{OH})\left(\mathrm{E}^{0}\right.$ varied between +1.8 and $+2.7 \mathrm{~V}$ versus $\left.\mathrm{NHE}\right)$ [19]. Such a high $\mathrm{E}^{0}$ suggests $\mathrm{SO}_{4} \cdot{ }^{-}$can oxidize almost all organic compounds non-selectively and efficiently. Furthermore, the traditional Fenton system (dominating free radical is $\cdot \mathrm{OH}$ ) is only valid under acidic $\mathrm{pH}$ conditions, PS can remain reactive and stable under not only acidic but also neutral and alkaline $\mathrm{pH}$ conditions [18]. Moreover, longer lifespan of $\mathrm{SO}_{4} .^{-}$makes it is superior to $\cdot \mathrm{OH}[20]$.

In order to make full use of every space of PFC system to expand photocatalytic redox reactions and further improve the performance of PFC, PFC was combined with PS to develop PFC/PS system for simultaneous organic pollutants degradation and electricity production in this work. In this system, a refractory organic pollutant, norfloxacin (NOR), was chosen to be the degradation target organic pollutant. NOR as a kind of fluoroquinolones is one of the most commonly prescribed 
antibiotics in human practice. It is worth noting that in China, half of the annual production of NOR are generally used as additives in concentrated pig feeding to promote the growth of pigs [21]. It has been reported that the presence of NOR in aquatic environment is toxic to plants and aquatic organisms [22,23], can cause bacterial drug resistance [24], and pose serious threats to human health [25]. Meanwhile, considering the antibacterial property, antibiotics could not be completely removed by traditional biological treatment. The effective degradation of antibiotics, especially NOR, in the aquatic environment has become the subject of growing concern.

In the present work, the rutile $\mathrm{TiO}_{2}$ nanorod directly growing on Fluorine-doped tin oxide (FTO) was employed as the photoanode material because of its better thermostability, smaller band gap, higher refractive index, and more active photocatalysis than anatase $\mathrm{TiO}_{2}$ [26-28]. UV light was used to activate PS in the solution and $\mathrm{TiO}_{2}$ photoanode simultaneously. Additionally, $\mathrm{PS}$ as a photogenerated electron sacrificial agent in PFC/PS system could not only improve the photogenerated charge separation on the surface of electrodes but also produce $\mathrm{SO}_{4} \cdot{ }^{-}$and further initiate a series of radical propagation and termination chain reactions in solution. Accordingly, in a PFC/PS system, the radical reactions are no longer confined to the single electrodes-electrolyte interface and the relatively low mass transport in the solution is no longer influenced by the reaction rate. The results demonstrated that the PS addition in PFC dramatically improved the NOR degradation efficiency and electricity generation of traditional PFC. In addition, to find the optimal conditions to degrade NOR, the influence factors were investigated systematically in PFC/PS system. According to the analysis, the results of radicals capture experiments, the dominant radicals species and the function mechanism for the NOR degradation were discussed. The total organic carbon (TOC) removal and real wastewater treatment experiments were conducted to study the NOR mineralization and potential practical applicability of the proposed PFC/PS system.

\section{Results and Discussion}

\subsection{Crystalline Phase and Morphology of $\mathrm{TiO}_{2}$ Nanorods}

In order to qualitatively and quantitatively analyze the phase composition of as-prepared samples, X-ray diffraction (XRD) patterns of $\mathrm{FTO}, \mathrm{TiO}_{2} / \mathrm{FTO}$ before anneal, and $\mathrm{TiO}_{2} / \mathrm{FTO}$ after anneal were recorded in Figure 1. From Figure 1, expect the diffraction peaks (denoted by "\#") indexed to FTO (Figure 1a), the other diffraction peaks (denoted by "**) of $\mathrm{TiO}_{2} / \mathrm{FTO}$ before anneal (Figure $1 \mathrm{~b}$ ) can be well identified as $\mathrm{TiO}_{2}$ with the tetragonal rutile crystal (JCPDS No. 21-1276). No characteristic peak assigned to anatase or brookite phase was detected, indicating the high purity of $\mathrm{TiO}_{2}$ prepared by hydrothermal method in this work. After being annealed at $450{ }^{\circ} \mathrm{C}$ for $90 \mathrm{~min}$, the peaks assigned to rutile $\mathrm{TiO}_{2}$ became sharper and the relative intensities were significantly enhanced. Moreover, no additional diffraction peak was observed (Figure 1c). These results indicate that the heat treatment not only not destroyed the crystal structure, it also improved the crystalline quality of rutile $\mathrm{TiO}_{2}$.

The morphology of as-prepared $\mathrm{TiO}_{2} /$ FTO was observed by scanning electron microscopy (SEM). It can be seen from Figure 2a that the surface of FTO electrode is uniformly covered by high-density $\mathrm{TiO}_{2}$ nanorods. Figure $2 \mathrm{~b}$ displays the terraced top surface of the $\mathrm{TiO}_{2}$ nanorods, which is tetragonal in shape. This is in perfect agreement with XRD results. Furthermore, the edge length of the square top facets is about $200 \mathrm{~nm}$. Figure $2 \mathrm{c}$ and d show that the $\mathrm{TiO}_{2}$ nanorods with a smooth side face and a $3 \mu \mathrm{m}$ length grew nearly perpendicular to the FTO electrode. 


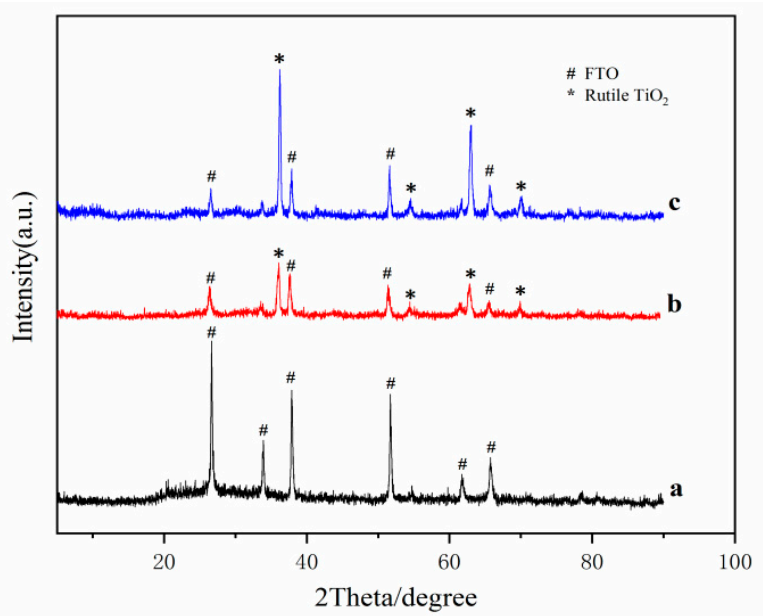

Figure 1. X-ray diffraction (XRD) patterns of Fluorine-doped tin oxide (FTO) (a), $\mathrm{TiO}_{2} /$ FTO before anneal $(\mathbf{b})$ and $\mathrm{TiO}_{2} / \mathrm{FTO}$ after anneal (c).
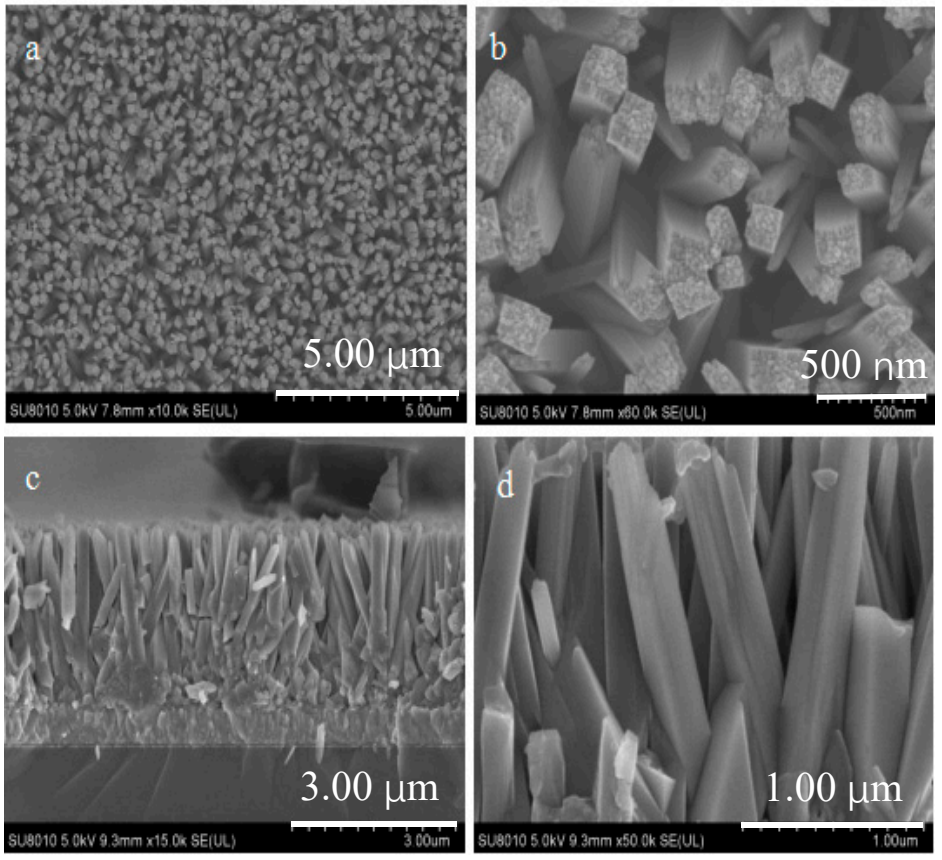

Figure 2. Scanning electron microscopy (SEM) images of as-prepared $\mathrm{TiO}_{2}$ photoanode. The micro scale (a) and nano scale (b) top view, cross-sectional view (c), and partially enlarged cross-sectional view (d).

\subsection{Performance Comparison of Different Systems}

The degradation experiments of $10 \mathrm{mg} / \mathrm{L}$ NOR in the three different systems were conducted to investigated the performance of these systems. Figure 3a compares the degradation results in different systems. The results are described as degradation efficiency versus degradation time. Figure 3a illustrates that after a 60 -min treatment, only $8.70 \%$ of NOR was decomposed in the PFC system alone. The reason for this low degradation efficiency may be attributed to the restricted reactions of radicals and NOR at the single photoelectrodes-electrolyte interface in PFC system [16]. On the other hand, the surface area of $\mathrm{TiO}_{2}$ photoanode is only $2 \mathrm{~cm}^{2}$ in this work. On the other hand, the 60-min degradation efficiency of NOR was improved to $77.17 \%$ in the PS system, which may be due to the fact that the strong oxidizing property of the persulfate aion $\left(\mathrm{S}_{2} \mathrm{O}_{8}{ }^{2-}\right)$ is beneficial to the degradation of NOR. 
Additionally, the sulfate radical $\left(\mathrm{SO}_{4} \cdot \cdot^{-}\right)$formed from PS by UV activation is superior to $\cdot \mathrm{OH}$ generated from PFC system and has the high reactivity for NOR degradation [20,29].
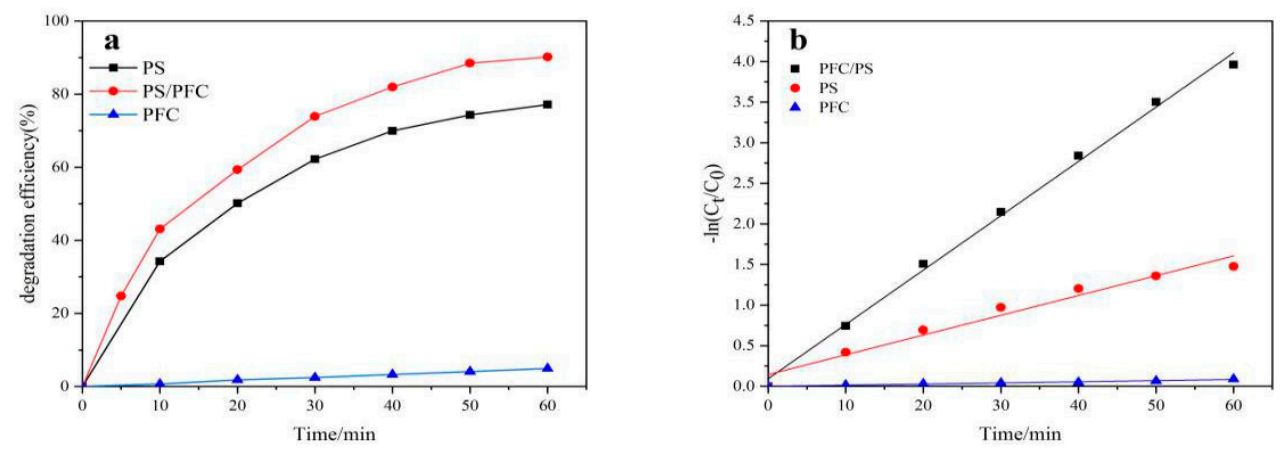

Figure 3. Degredation efficiency of $10 \mathrm{mg} / \mathrm{L}$ norfloxacin (NOR) in photocatalytic fuel cell (PFC), persulfate (PS), and PFC/PS system under ultraviolet (UV) light irradiation (a) and its pseudo first-order kinetic fit (b). Experimental conditions: $\mathrm{pH}=3.0,[\mathrm{PS}]=3 \mathrm{mM}$, and electrolyte: $0.1 \mathrm{M} \mathrm{Na}_{2} \mathrm{SO}_{4}$.

When PFC and PS were both applied to the degradation of NOR, the degradation efficiency of NOR was further improved to $98.10 \%$, indicating a good synergistic effect between PFC and PS.

In addition, according to the analysis of degradation kinetics, the pseudo first-order kinetic equation was found to fit the experimental data well (Figure $3 b$ ). The kinetic parameters including apparent rate constant $\mathrm{k}$ and correlation coefficient $\mathrm{R}^{2}$ for each system are listed in Table 1. It shows that $\mathrm{k}$ in the PFC/PS system $\left(6.69 \times 10^{-2} \mathrm{~min}^{-1}\right)$ is the greatest, that in PS $\left(2.44 \times 10^{-2} \mathrm{~min}^{-1}\right)$ is the second, and that in PFC $\left(1.40 \times 10^{-3} \mathrm{~min}^{-1}\right)$ is the smallest, which is in accordance with the variation tendency of NOR degradation. These results demonstrate that the superior performance of PFC/PS combined system for accelerating the degradation of NOR.

Table 1. The kinetic parameters of norfloxacin (NOR) degradation in different systems.

\begin{tabular}{ccc}
\hline Process & Apparent Rate Constant, k (min $\left.\mathbf{m i}^{\mathbf{1}}\right)$ & $\mathbf{R}^{\mathbf{2}}$ \\
\hline Photocatalytic fuel cell (PFC) & $1.40 \times 10^{-3}$ & 0.9821 \\
Persulfate (PS) & $2.44 \times 10^{-2}$ & 0.9654 \\
PFC/PS & $6.69 \times 10^{-2}$ & 0.9962 \\
\hline
\end{tabular}

Figure 4 shows the current-voltage (I-V) curves and the corresponding power density curves of PFC and PFC/PS system to compare their electricity generation performance. Obviously, the PFC/PS system exhibits the better electricity generation performance with an open-circuit potential (Voc) of $0.5 \mathrm{~V}$ and a short-circuit current density (Jsc) of $0.290 \mathrm{~mA} \cdot \mathrm{cm}^{-2}$, with $0.4 \mathrm{~V}$ and $0.270 \mathrm{~mA} \cdot \mathrm{cm}^{-2}$, respectively, for the PFC system (Figure $4 \mathrm{a})$. The maximum output power $\left(\mathrm{P}_{\mathrm{Max}}\right)$ of PFC/PS is 0.036 $\mathrm{mW} \cdot \mathrm{cm}^{-2}$, which is nearly two times higher than that in the PFC system $\left(0.018 \mathrm{~mW} \cdot \mathrm{cm}^{-2}\right)$ (Figure $\left.4 \mathrm{~b}\right)$. These results reveal the efficient electricity output of PFC/PS system and such a high performance is attributed to the synergy of PFC and PS. 

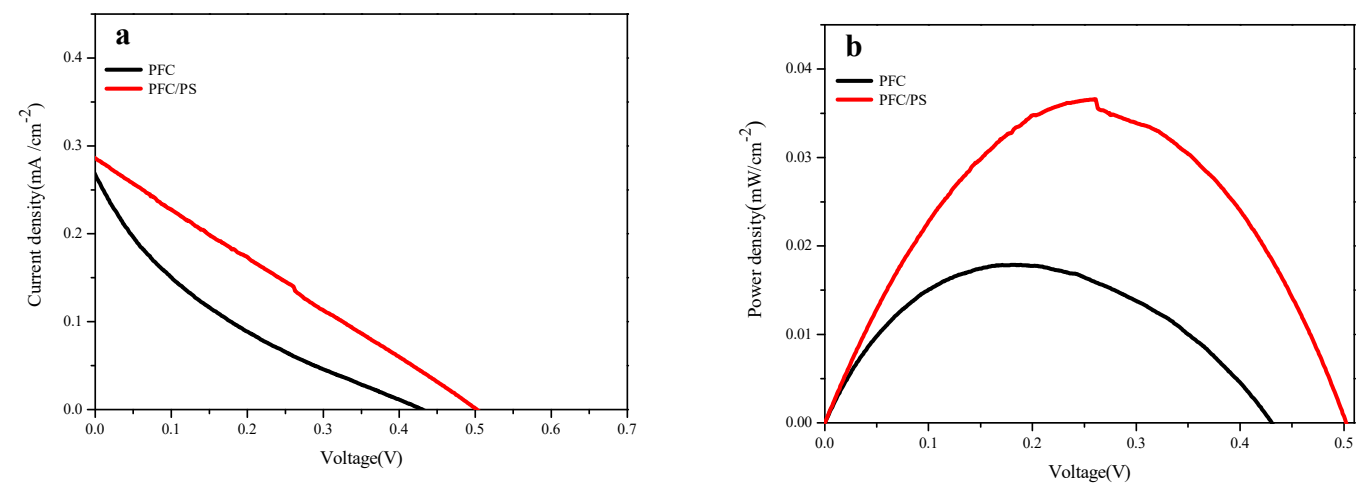

Figure 4. The current-voltage (I-V) characteristic curves (a) and the corresponding power density curves (b) of the PFC and PFC/PS systems. Experimental conditions: $\mathrm{pH}=3.0,[\mathrm{NOR}]=10 \mathrm{mg} / \mathrm{L}$, [PS] $=3 \mathrm{mM}$, and electrolyte: $0.1 \mathrm{M} \mathrm{Na}_{2} \mathrm{SO}_{4}$.

For the original PFC system, under the irradiation of UV light, $\mathrm{TiO}_{2}$ nanorods could adsorb adequate photons and produce photogenerated holes $\left(\mathrm{h}^{+}\right)$and electrons $\left(\mathrm{e}^{-}\right)$. The former, as the oxidizing agent, can directly react with NOR; the latter can transfer from the $\mathrm{TiO}_{2}$ nanorods to the cathode through the external circuit and generate electric power [30]. Simultaneously, a series of photocatalytic redox reaction can occur among $\mathrm{h}^{+}, \mathrm{e}^{-}, \mathrm{O}_{2}$, and $\mathrm{H}_{2} \mathrm{O}$, producing numerous reactive oxygen species such as $\cdot \mathrm{OH}, \mathrm{HO}_{2}, \mathrm{H}_{2} \mathrm{O}_{2}$, and $\mathrm{O}_{2} \cdot{ }^{-}$, which play a crucial and positive role in the decomposition of NOR [10,31]. However, the recombination of photogenerated electron-hole pairs on the surface and in the interior of $\mathrm{TiO}_{2}$ nanorods would also occur at the same time; then, the reactions between NOR and active species would be limited to the finite photoelectrodes-electrolyte interface [32,33]. Therefore, the NOR degradation and electricity production of PFC can be hindered.

When the PS was introduced into the PFC system, a part of NOR was chemically oxidized because of the strong oxidizing property of PS itself $[34,35]$. On the other hand, the addition of PS could increase the amount of supporting electrolyte, which can enhance the electrical conductivity and facilitate electron transfer and the separation of photogenerated electron-hole pairs. Then, as a stable and long-life radical, $\mathrm{SO}_{4} \cdot{ }^{-}$could be generated not only in the entire solution by activation of PS under UV light irradiation, but also at the interface of photoelectrodes-electrolyte by the direct reaction of PS and $\mathrm{e}^{-}$. In this reaction, PS acts as an electron acceptor [36,37]. The production of $\mathrm{SO}_{4} .^{-}$can increase the number of active radicals, reduce the recombination of photogenerated electron-hole pairs, and even extend the range of reactions between active species and NOR from interface of photoelectrodes-electrolyte to the total solution, which efficiently improve the PFC performance and benefit the degradation of NOR. At the same time, the consumption of $\mathrm{SO}_{4} \cdot{ }^{-}$during the degradation of NOR can accelerate the photogenerated electron transfer, which is advantageous to the higher electricity generation [38]. Thus, the PFC/PS system was used in the following experiments unless otherwise specified.

\subsection{Effect of $\mathrm{pH}$}

In order to clarify the effect of $\mathrm{pH}$, the NOR degradation processes were carried out at different initial solution $\mathrm{pH}$ values in PFC/PS system. As shown in Figure 5a, during the first $30 \mathrm{~min}$, the degradation efficiency increased with a decreasing initial solution $\mathrm{pH}$ from 11.0 to 3.0. Nevertheless, when the initial solution $\mathrm{pH}$ further decreased to 1.0, the degradation efficiency slightly reduced compared with that at initial solution $\mathrm{pH}$ 3.0. With prolonging the degradation time, the degradation efficiency continuously increased when the initial solution $\mathrm{pH}$ values were 3.0, 5.0, 7.0, 9.0, and 11.0. To the contrary, the degradation efficiency remained unchanged at the initial solution $\mathrm{pH} 1.0$. Within $60 \mathrm{~min}$, the degradation efficiency varied decreasingly with the initial solution $\mathrm{pH}$ value in the following sequence: $3.0,5.0,7.0,1.0,9.0$, and 11.0. The maximum degradation efficiency was $97.19 \%$ at 
$\mathrm{pH}$ 3.0. However, the variation of 60-min degradation efficiency was not so remarkable. According to the pseudo first-order kinetic analysis (Figure $5 \mathrm{~b}$ ), the corresponding apparent rate constant values $(\mathrm{k})$ for NOR degradation at $\mathrm{pH}$ of 3.0, 5.0, 7.0, 1.0, 9.0, and 11.0 were $5.64 \times 10^{-2} \mathrm{~min}^{-1}, 4.79 \times 10^{-2} \mathrm{~min}^{-1}$, $4.10 \times 10^{-2} \mathrm{~min}^{-1}, 3.96 \times 10^{-2} \mathrm{~min}^{-1}, 3.56 \times 10^{-2} \mathrm{~min}^{-1}$, and $2.99 \times 10^{-2} \mathrm{~min}^{-1}$, respectively (Table 2). The decomposition of NOR and the variation of $k$ were identical.
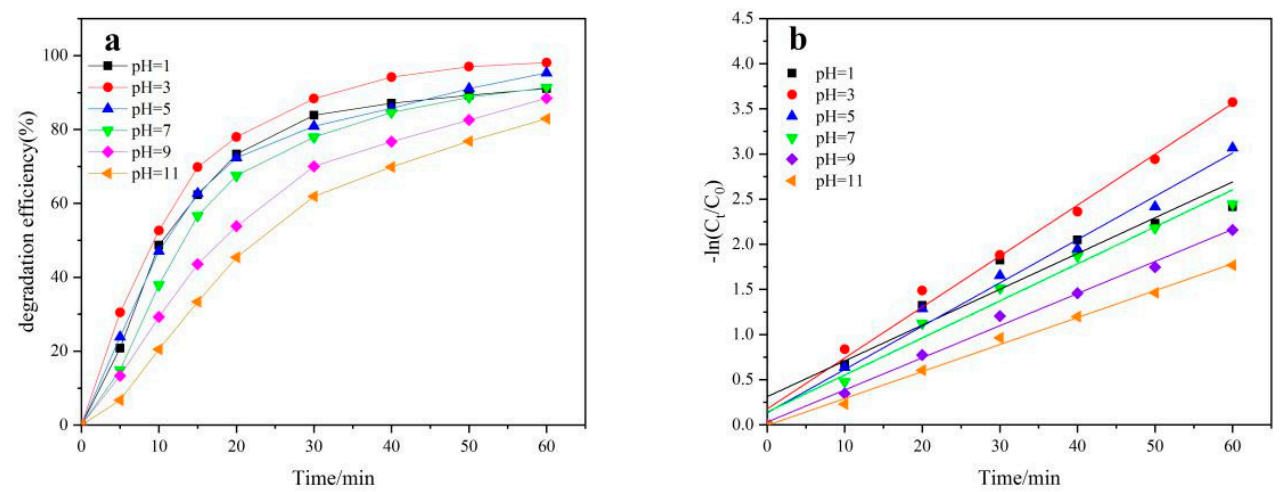

Figure 5. Effect of initial solution $\mathrm{pH}$ on degradation efficiency of NOR (a) and the corresponding pseudo first-order kinetics (b). Experimental conditions: $[\mathrm{NOR}]=10 \mathrm{mg} / \mathrm{L},[\mathrm{PS}]=2 \mathrm{mM}$, and electrolyte: $0.1 \mathrm{M} \mathrm{Na}_{2} \mathrm{SO}_{4}$.

Table 2. The kinetic parameters of NOR degradation at different initial $\mathrm{pH}$ values.

\begin{tabular}{ccc}
\hline Initial $\mathbf{p H}$ value & Apparent Rate Constant, $\mathbf{k}\left(\mathbf{m i n}^{\mathbf{- 1})}\right.$ & $\mathbf{R}^{\mathbf{2}}$ \\
\hline $\mathrm{pH}=1$ & $3.96 \times 10^{-2}$ & 0.9259 \\
$\mathrm{pH}=3$ & $5.64 \times 10^{-2}$ & 0.9908 \\
$\mathrm{pH}=5$ & $4.79 \times 10^{-2}$ & 0.9863 \\
$\mathrm{pH}=7$ & $4.10 \times 10^{-2}$ & 0.9782 \\
$\mathrm{pH}=9$ & $3.56 \times 10^{-2}$ & 0.9947 \\
$\mathrm{pH}=11$ & $2.99 \times 10^{-2}$ & 0.9957 \\
\hline
\end{tabular}

These phenomena may be ascribed to that the initial solution $\mathrm{pH}$ affects the dominant species of radical oxidants during the NOR degradation process and finally influences the performance of PFC/PS system. It has been widely reported that in an acidic and neutral medium, the predominate radical species is $\mathrm{SO}_{4} \cdot{ }^{-}$, and converts to $\cdot \mathrm{OH}$ with increasing the $\mathrm{pH}$ to alkaline value [39]. In an acidic environment, $\mathrm{SO}_{4} \cdot{ }^{-}$can be formed via the breakdown of persulfate using acid as catalyst (Equations (1)-(3)) [40-42].

Once $\mathrm{SO}_{4} \cdot^{-}$is formed, it can attack nearly any organic contaminant, including NOR. In contrast, under neutral or basic condition, $\mathrm{SO}_{4} .^{-}$formed in aqueous solution can react with $\mathrm{H}_{2} \mathrm{O}$ or $\mathrm{OH}^{-}$leading to radical inter-conversion to produce the hydroxyl radical $(\cdot \mathrm{OH})$ in accordance with forward reactions in Equations (4) and (5). In addition, the generated $\cdot \mathrm{OH}$ can further react with $\mathrm{SO}_{4} \cdot{ }^{-}$to scavenge both of themselves (Equation (6)). On the account of the weaker redox ability of $\cdot \mathrm{OH}$ than $\mathrm{SO}_{4} \cdot{ }^{-}$ and the quenching of $\cdot \mathrm{OH}$ and $\mathrm{SO}_{4} \cdot^{-}$, acidic condition was more favorable than neutral and alkaline environments for NOR degradation.

$$
\begin{gathered}
\mathrm{S}_{2} \mathrm{O}_{8}{ }^{2-}+\mathrm{H}^{+} \rightarrow \mathrm{HS}_{2} \mathrm{O}_{8}, \\
\mathrm{HS}_{2} \mathrm{O}_{8}{ }^{-} \rightarrow \mathrm{SO}_{4} \cdot^{-}+\mathrm{HSO}_{4}{ }^{-}, \\
\mathrm{HSO}_{4}{ }^{-} \rightarrow \mathrm{SO}_{4}{ }^{2-}+\mathrm{H}^{+}(\mathrm{pKa}=1.92), \\
\mathrm{SO}_{4} \cdot^{-}+\mathrm{H}_{2} \mathrm{O} \rightarrow \mathrm{SO}_{4}{ }^{2-}+\cdot \mathrm{OH}+\mathrm{H}^{+}, \\
\mathrm{SO}_{4}{ }^{-}+\mathrm{OH}^{-} \rightarrow \mathrm{SO}_{4}{ }^{2-}+\cdot \mathrm{OH},
\end{gathered}
$$




$$
\begin{gathered}
\mathrm{SO}_{4} \cdot^{-}+\cdot \mathrm{OH} \rightarrow \mathrm{HSO}_{5}{ }^{-}, \\
\mathrm{S}_{2} \mathrm{O}_{8}{ }^{2-}+\mathrm{H}_{2} \mathrm{O} \rightarrow 2 \mathrm{HSO}_{4^{-}}+\frac{1}{2} \mathrm{O}_{2},
\end{gathered}
$$

Since the pKa value for the system of bisulfate and sulfate ions is 1.92 , the initial solution $\mathrm{pH}$ below 1.92 can restrain the reaction in Equation (3), then in Equation (2), and give rise to the decline in the generation of $\mathrm{SO}_{4} \cdot{ }^{-}$. Therefore, the initial solution $\mathrm{pH}$ is usually greater than 1.92 to improve the degradation of NOR. This can explain the results shown in Figure 5, in that the degradation efficiency of NOR and the corresponding apparent rate constant value at $\mathrm{pH} 1.0$ were lower than that at $\mathrm{pH} 3.0$, 5.0, and 7.0.

Furthermore, on the one hand, vast hydrogen ions are released into the water, resulting in the decrease of $\mathrm{pH}$ according to the reactions in Equations (3) and (7) [43]. On the other hand, upon the mineralization of organic pollutants, acidic $\mathrm{CO}_{2}$ is one of the final products that diminishes the $\mathrm{pH}$ values. Consequently, a common issue pertaining to the oxidation of organic contaminants by activated persulfate is that the $\mathrm{pH}$ values in an aqueous phase usually decreases and are lower than the initial data [39], indicating the initial solution $\mathrm{pH}$ value has little impact on the oxidation environment. This is why the variation of degradation efficiency and corresponding apparent rate constant value at different initial solution $\mathrm{pH}$ value is not obvious after $60 \mathrm{~min}$ reaction in Figure 5.

\subsection{Effect of the PS Concentration}

It was reported that the PS concentration was found to have an obvious effect on the oxidation of organic contaminants [44]. The variation of 60-min degradation efficiency of NOR in the PFC/PS system with different PS concentrations was studied. It is clearly observed that the degradation efficiency of NOR was drastically enhanced with increasing the PS concentration from $0.1 \mathrm{mM}$ to $3.0 \mathrm{mM}$. Figure 6a displays that the degradation efficiency of NOR increased greatly from $52.77 \%$ to $98.10 \%$, while PS concentration showed an increasing trend from $0.1 \mathrm{mM}$ to $3.0 \mathrm{mM}$. Figure $6 \mathrm{a}$ also shows that when the PS concentration rose further from $3.0 \mathrm{mM}$ to $4.0 \mathrm{mM}$, the degradation efficiency of NOR was approximately similar with that $3.0 \mathrm{mM}$ PS and no remarkable change was observed. Moreover, the pseudo first-order kinetics fitting results demonstrate that the maximum $\mathrm{k}$ values were obtained when PS concentration was $3.0 \mathrm{mM}\left(6.69 \times 10^{-2} \mathrm{~min}^{-1}\right)$ and $4.0 \mathrm{mM}\left(6.95 \times 10^{-2} \mathrm{~min}^{-1}\right)$ (Figure $6 \mathrm{~b}$ and Table 3); the latter is slightly higher than the former.
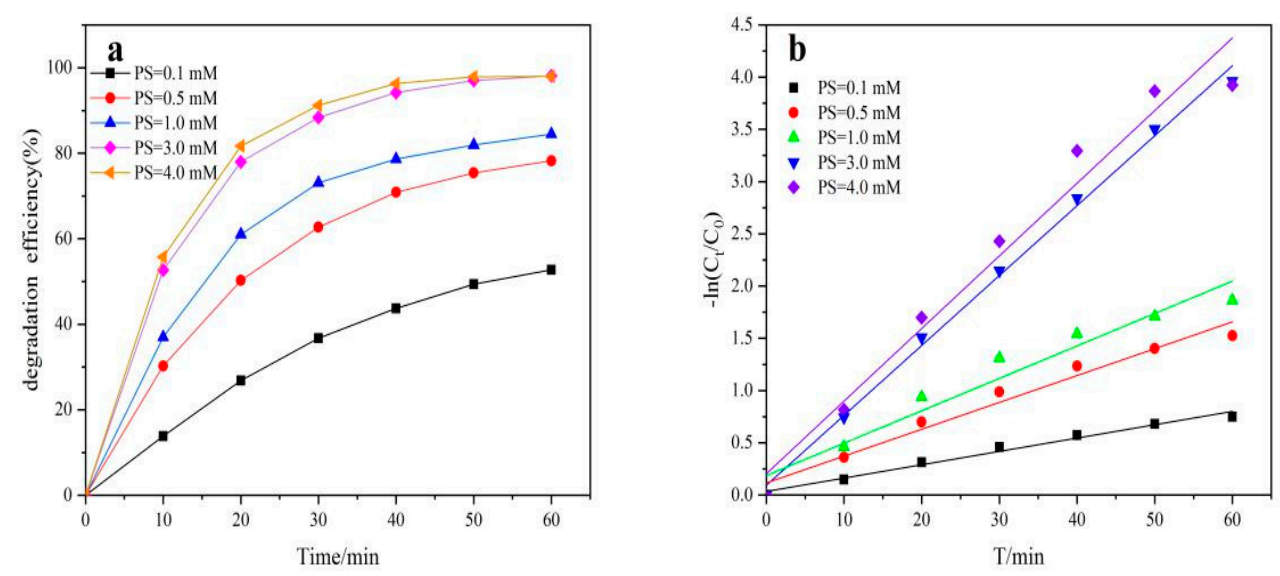

Figure 6. Effect of PS concentration on degradation efficiency of NOR (a) and the corresponding pseudo first-order kinetics fitting (b). Experimental conditions: [NOR] $=10 \mathrm{mg} / \mathrm{L}, \mathrm{pH}=3$, and electrolyte: $0.1 \mathrm{M} \mathrm{Na}_{2} \mathrm{SO}_{4}$. 
Table 3. The kinetic parameters of NOR degradation at different PS concentrations.

\begin{tabular}{ccc}
\hline PS Concentration $(\mathbf{m M})$ & Apparent Rate Constant, $\mathbf{~ ( \mathbf { m i n } ^ { - 1 } )}$ & $\mathbf{R}^{\mathbf{2}}$ \\
\hline 0.1 & $1.28 \times 10^{-2}$ & 0.9850 \\
0.5 & $2.57 \times 10^{-2}$ & 0.9716 \\
1.0 & $3.10 \times 10^{-2}$ & 0.9509 \\
3.0 & $6.69 \times 10^{-2}$ & 0.9962 \\
4.0 & $6.95 \times 10^{-2}$ & 0.9703 \\
\hline
\end{tabular}

Two reasons could be used to explain these results. Firstly, a relatively lower PS concentration results in insufficient number of $\mathrm{SO}_{4} \cdot{ }^{-}$, which is not conducive to the degradation of NOR. Secondly, according to Equations (8) and (9), additional $\mathrm{SO}_{4} \cdot{ }^{-}$formed at excessive PS concentration can react with itself and excessive persulfate to produce $\mathrm{SO}_{4}{ }^{2-}$ and less-reactive $\mathrm{S}_{2} \mathrm{O}_{8}{ }^{-{ }^{-}}$, respectively [36,45]. These reactions can reduce the number of strong radicals and pose competition between NOR and excessive persulfate, inhibiting the degradation of NOR. As a consequence, in consideration of economy and efficiency, a PS concentration of $3.0 \mathrm{mM}$ was chosen for further experimentation in this work.

$$
\begin{gathered}
2 \mathrm{SO}_{4} .^{-} \rightarrow 2 \mathrm{SO}_{4}{ }^{2-}, \\
\mathrm{SO}_{4} \cdot^{-}+\mathrm{S}_{2} \mathrm{O}_{8}{ }^{-} \rightarrow \mathrm{S}_{2} \mathrm{O}_{8} \cdot{ }^{-}+\mathrm{SO}_{4}{ }^{2-},
\end{gathered}
$$

\subsection{Effect of Initial NOR Concentration}

The effect of initial concentration of NOR was investigated (Figure 7). As shown in Figure 7a, the degradation efficiency of NOR was reduced sharply from $98.10 \%$ to $12.92 \%$ with increasing NOR concentration from $10 \mathrm{mg} / \mathrm{L}$ to $200 \mathrm{mg} / \mathrm{L}$. All the degradation processes at different NOR concentrations were fitted well with pseudo first-order kinetics model (Figure $7 \mathrm{~b}$ ) and the calculated rate constants and other parameters were exhibited in Table 4 . The variation of the rate constants is similar to that of degradation efficiency. Namely, the corresponding rate constant decreased gradually from $6.69 \times 10^{-2}$ to $2.70 \times 10^{-3} \mathrm{~min}^{-1}$, with an increasing NOR concentration from 10 to $200 \mathrm{mg} / \mathrm{L}$.
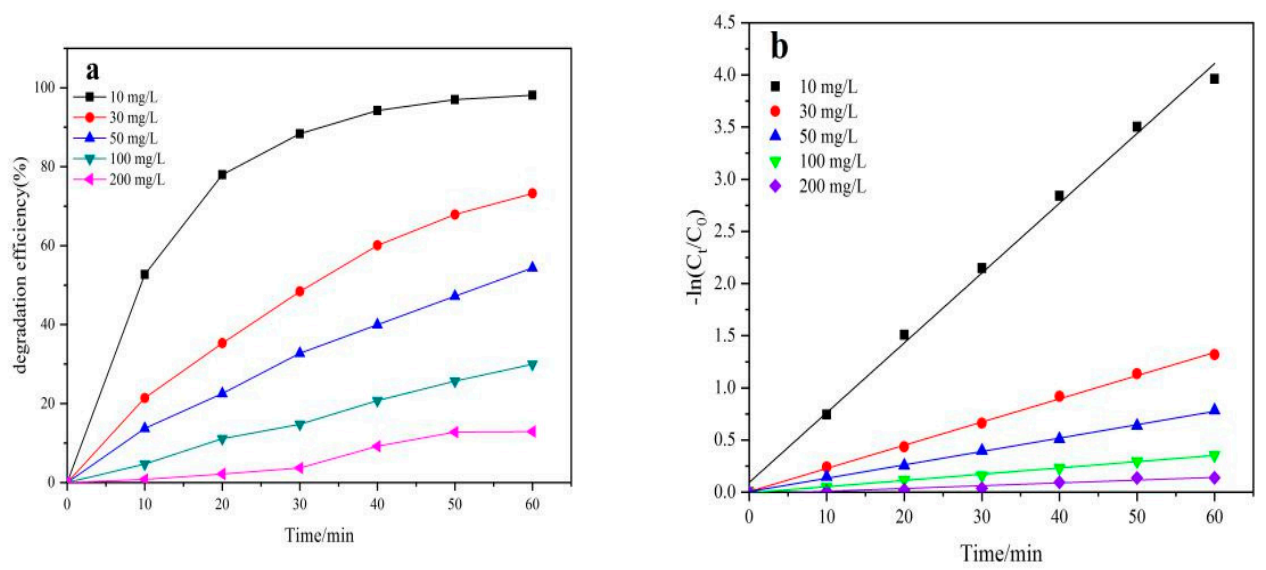

Figure 7. Effect of initial NOR concentration on the degradation efficiency of NOR (a) and the corresponding pseudo first-order kinetics fitting (b). Experimental conditions: $[\mathrm{PS}]=3 \mathrm{mM}, \mathrm{pH}=3$, and electrolyte: $0.1 \mathrm{M} \mathrm{Na}_{2} \mathrm{SO}_{4}$. 
Table 4. The kinetic parameters of NOR degradation at different initial NOR concentrations.

\begin{tabular}{ccc}
\hline Process, $\left.\mathbf{C}_{\mathbf{N O R}} / \mathbf{( m g} / \mathbf{L}\right)$ & Apparent Rate Constant, $\mathbf{k}\left(\mathbf{m i n}^{-\mathbf{1}}\right)$ & $\mathbf{R}^{\mathbf{2}}$ \\
\hline 10 & $6.69 \times 10^{-2}$ & 0.9962 \\
30 & $2.22 \times 10^{-2}$ & 0.9986 \\
50 & $1.28 \times 10^{-2}$ & 0.9988 \\
100 & $6.00 \times 10^{-3}$ & 0.9971 \\
200 & $2.70 \times 10^{-3}$ & 0.9243 \\
\hline
\end{tabular}

These results may be due to the reasons as follows. On the one hand, the active sites of $\mathrm{TiO}_{2}$ nanorods are limited depending on the fixed area of $\mathrm{TiO}_{2}$ nanorods photoanode. During the photocatalytic process, NOR should be firstly absorbed on the active sites of $\mathrm{TiO}_{2}$ nanorods and then react with free radicals to complete the photocatalytic process. Thus, excessive initial NOR concentration will lead to the competition for limited active sites, suppressing the degradation efficiency of NOR. On the other hand, the more NOR and its intermediates will exist in the system with an increase of the initial NOR concentration, resulting in more competition for active radicals such as $\cdot \mathrm{OH}$ and $\mathrm{SO}_{4} \cdot{ }^{-}$. However, since the key factors for active radical generation, including PS concentration, UV light irradiation intensity, and the area of $\mathrm{TiO}_{2}$ nanorods photoanode, are fixed, the number of active radicals is limited. The NOR will be efficiently degraded until all the active radicals are consumed. Ultimately, the degradation efficiency of NOR is decreased.

\subsection{The Mineralization of NOR in PFC/PS System}

In order to investigate the mineralized degree of NOR, the TOC variation of the NOR solution with an initial concentration of $10 \mathrm{mg} / \mathrm{L}$ during the degradation process in PFC/PS system was analyzed. The degradation experiment was performed under the optimal conditions $(\mathrm{pH}=3.0,[\mathrm{PS}]=3 \mathrm{mM}$, and $0.1 \mathrm{M} \mathrm{Na}_{2} \mathrm{SO}_{4}$ as electrolyte). As shown in Figure 8, the TOC removal efficiency was lower than the degradation efficiency at the same treatment time. Within $60 \mathrm{~min}$, the degradation efficiency of NOR reached $98.1 \%$, indicating that NOR was almost completely degraded. At the same time, the TOC removal efficiency was only $72.3 \%$, which suggested that despite the fact that $27.7 \%$ NOR had been transformed to its intermediates, the PFC/PS system still had the capacity to effectively degrade NOR under the optimal conditions. After a further prolonging 20-min treatment time, it was observed that the TOC removal efficiency reached $90.5 \%$, showing the hysteresis quality of NOR mineralization and the potential of PFC/PS system in refractory organic pollutant treatment.

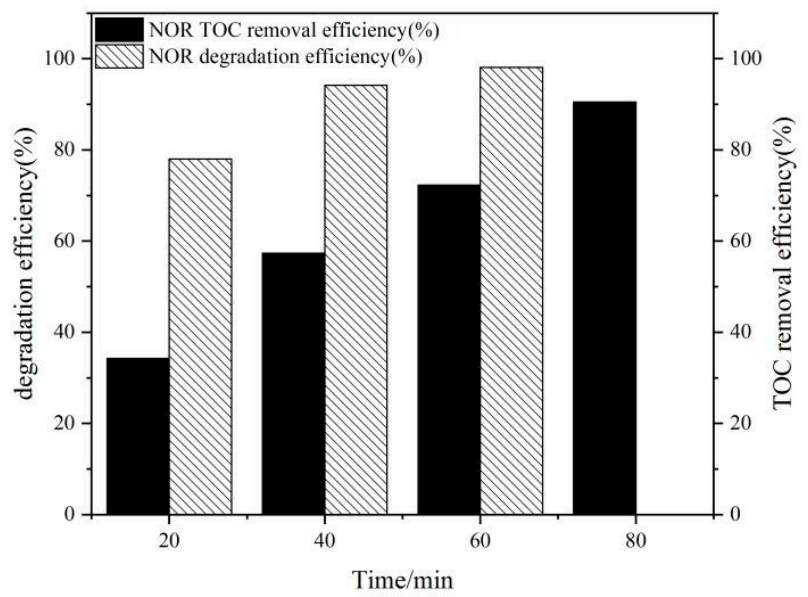

Figure 8. The degradation efficiency and the total organic carbon (TOC) removal efficiency of NOR with $10 \mathrm{mg} / \mathrm{L}$ initial concentration in PFC/PS system. Experimental conditions: $[\mathrm{PS}]=3 \mathrm{mM}, \mathrm{pH}=3$, and electrolyte: $0.1 \mathrm{M} \mathrm{Na}_{2} \mathrm{SO}_{4}$. 


\subsection{Roles of Different Reactive Radical Species in PFC/PS System}

As is well-known, the degradation of organic pollutants during photocatalytic process and activated persulfate oxidation process is completed by the generation of various reactive radical species. Next, we need to identify the predominant radicals and clarify whether the roles of different reactive radical species in the PFC/PS system are significant and conductive to better elucidate the function mechanism of enhanced NOR degradation in the PFC/PS system. It has been reported that scavengers can react with reactive radical species both generated on the catalyst surface and in the solution. Therefore, a series of radicals quenching experiments were conducted by adding $0.3 \mathrm{M}$ ethanol $(\mathrm{EtOH}$, as a scavenger of both $\mathrm{SO}_{4} \cdot{ }^{-}$and $\cdot \mathrm{OH}$ ) [38], $0.3 \mathrm{M}$ isopropanol (IPA, as a specific $\cdot \mathrm{OH}$ scavenger) [46-48], and $4 \mathrm{mM}$ EDTA-2Na (as a typical quenching agent for $\mathrm{h}^{+}$) [49] into the degradation solution of NOR with $10 \mathrm{mg} / \mathrm{L}$ initial concentration. In addition, since the formation of $\mathrm{O}_{2} \cdot{ }^{-}$is due to the reduce reaction between molecular oxygen adsorbed on the surface of catalyst and photogenerated electron, nitrogen was continuously blown into the PFC/PS system to drive off oxygen and further inhibit the generation of $\mathrm{O}_{2}{ }^{-}$in a separate experiment. These experiments were carried out under the optimal condition in the PFC/PS system. The results are shown in Figure 9.

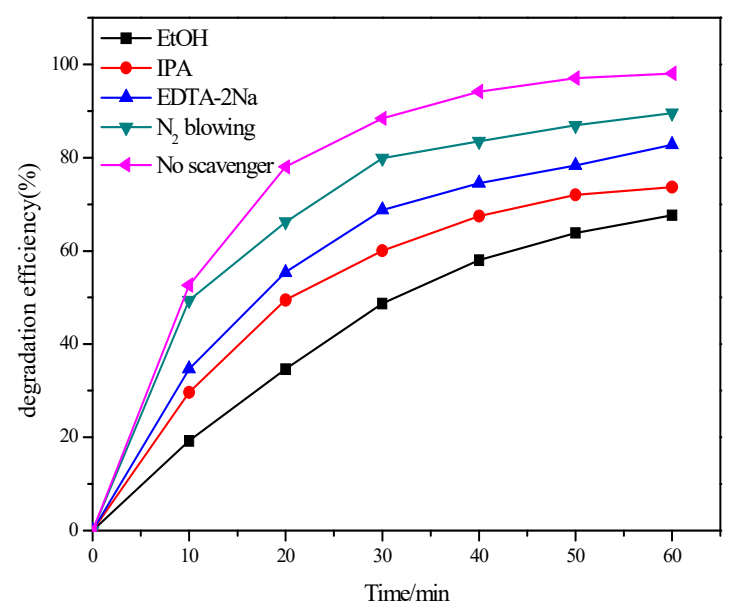

Figure 9. Effect of different reactive radical species on the degradation efficiency of NOR with $10 \mathrm{mg} / \mathrm{L}$ initial concentration in PFC/PS system. Experimental conditions: $[$ EtOH $]=[\mathrm{IPA}]=0.3 \mathrm{M}$, $[\mathrm{EDTA}-2 \mathrm{Na}]$ $=4 \mathrm{mM},[\mathrm{PS}]=3 \mathrm{mM}, \mathrm{pH}=3$, and electrolyte: $0.1 \mathrm{M} \mathrm{Na}_{2} \mathrm{SO}_{4}$.

As presented in Figure 9, 98.1\% of NOR was degraded after 60 min without any scavenger added. After bubbling nitrogen and adding EDTA-2Na, the 60-min degradation efficiency was slightly decreased by $8.6 \%$ and $15.33 \%$, respectively. Whereas, the degradation efficiency of NOR was obviously restrained in the presence of EtOH and IPA, separately. The 60-min degradation efficiency of NOR was greatly reduced to $67.7 \%$ and $73.6 \%$ with the addition of EtOH and IPA, respectively. These results indicate that the degradation of NOR was triggered by radicals. Moreover, the $\mathrm{O}_{2}{ }^{-}$and $\mathrm{h}^{+}$play a relatively minor role in the NOR degradation process, while $\cdot \mathrm{OH}$ and $\mathrm{SO}_{4} .^{-}$are the two main radicals contributed to the degradation of NOR. Therein, the NOR degradation efficiency of EtOH quenching declined more than that of IPA, which may be attributed to that IPA was more apt to react with -OH; nevertheless, $\mathrm{SO}_{4} 4^{-}$could react more readily with $\mathrm{NOR}$, suggesting that $\mathrm{SO}_{4} \cdot^{-}$radicals played a more dominant role in the NOR degradation process. These were in accordance with the results of $\mathrm{pH}$ effect experiment and those reported in the literature [38]. On the other hand, it is very interesting to observe from Figure 9 that after adding EtOH into the solution, a large amount of NOR were still degraded. EtOH can usually be applied to effectively quench both $\cdot \mathrm{OH}$ and $\mathrm{SO}_{4} \cdot{ }^{-}$due to its high rate constant of $1.9 \times 10^{9} \mathrm{M}^{-1} \mathrm{~S}^{-1}$ and $1.6 \times 10^{7} \mathrm{M}^{-1} \mathrm{~S}^{-1}$ for $\cdot \mathrm{OH}$ and $\mathrm{SO}_{4} .^{-}$, respectively [50,51]. However, it has been also reported that NOR also possessed similar high reaction rate constants with $\cdot \mathrm{OH}\left(\mathrm{k}=1.0 \times 10^{9} \mathrm{M}^{-1} \mathrm{~S}^{-1}\right)$ and $\mathrm{SO}_{4} \cdot{ }^{-}\left(\mathrm{k}=10^{7}-10^{10} \mathrm{M}^{-1} \mathrm{~S}^{-1}\right)$ [52]. In this case, the degradation 
of a large amount of NOR could most likely be attributed to that a part of $\cdot \mathrm{OH}$ and $\mathrm{SO}_{4} \cdot{ }^{-}$reacted referentially with NOR rather than EtOH. At this moment, the other radicals and $\mathrm{h}^{+}$also made a positive contribution to the degradation of NOR.

According to the aforementioned analysis, a tentative function mechanism for the degradation of NOR in PFC/PS system was proposed and illustrated in Scheme 1. In PFC/PS system, the degradation of NOR took place both in the solution and on the surface of $\mathrm{TiO}_{2}$ nanorods. Under the irradiation of UV light, the photogenerated hole and electron separated and transferred to the surface of $\mathrm{TiO}_{2}$ nanorods (Equation (10)). Then, a portion of the photogenerated hole directly participated in the degradation reaction of adsorbed $\mathrm{NOR}$ on the surface of $\mathrm{TiO}_{2}$ nanorods (Equation (11)), and a portion of $\mathrm{h}^{+}$reacted with water to produce $\cdot \mathrm{OH}$ (Equation (12)); the other part of the hole recombined with the electron inevitably. The limited quantity of $\mathrm{h}^{+}$showed that it played a minor role in the NOR degradation. After transferring to the surface of $\mathrm{Pt}$ electrode from $\mathrm{TiO}_{2}$ nanorods through the external circuit, electrons effectively excited the adsorbed PS molecules to decompose and generate $\mathrm{SO}_{4} .^{-}$ (Equation (13)). Moreover, the dissolved oxygen molecules could also react with electrons to form $\mathrm{O}_{2}{ }^{-}$ (Equation (14)). On the one hand, the content of dissolved oxygen molecules in the solution is low and constant; on the other hand, generated $\mathrm{O}_{2} \cdot{ }^{-}$could partially transformed into $\cdot \mathrm{OH}$ through the reaction with water in the solution (Equation (15)). Thus, $\mathrm{O}_{2} \cdot{ }^{-}$also played a minor role in the NOR degradation. In the solution, $\mathrm{SO}_{4} \cdot{ }^{-}$could also be generated via the UV light excitation of PS (Equation (16)). Under certain conditions, the transform reaction from generated $\mathrm{SO}_{4} \cdot{ }^{-}$to $\cdot \mathrm{OH}$ also occurred in the solution (Equations (4) and (5)). Finally, according to the Equations (11), (17)-(21), the degradation of NOR occurred both in the solution and on the surfaces of $\mathrm{TiO}_{2}$ nanorods by the oxidation of radicals $\left(\mathrm{O}_{2} \cdot{ }^{-}\right.$, $\left.\cdot \mathrm{OH}, \mathrm{SO}_{4} \cdot{ }^{-}\right), \mathrm{h}^{+}$, and PS.

$$
\begin{aligned}
& \mathrm{TiO}_{2} \stackrel{h v}{\rightarrow} \mathrm{h}^{+}+\mathrm{e}^{-}, \\
& \mathrm{h}^{+}+\mathrm{NOR} \rightarrow \mathrm{CO}_{2}+\mathrm{H}_{2} \mathrm{O}+\text { intermediate } \\
& \mathrm{H}_{2} \mathrm{O}+\mathrm{h}^{+} \rightarrow \cdot \mathrm{OH}+\mathrm{H}^{+}, \\
& \mathrm{S}_{2} \mathrm{O}_{8}{ }^{2-}+\mathrm{e}^{-} \rightarrow \mathrm{SO}_{4} \cdot^{-}+\mathrm{SO} 4^{2-} \text {, } \\
& \mathrm{O}_{2}+\mathrm{e}^{-} \rightarrow \mathrm{O}_{2} \cdot{ }^{-} \text {, } \\
& \mathrm{O}_{2} \cdot{ }^{-}+\mathrm{H}_{2} \mathrm{O} \rightarrow \mathrm{OH}^{-}+\cdot \mathrm{OH} \text {, } \\
& \mathrm{S}_{2} \mathrm{O}_{8}{ }^{2-} \stackrel{h v}{\rightarrow} 2 \mathrm{SO}_{4} \cdot^{-}, \\
& \mathrm{SO}_{4} \cdot{ }^{-}+\mathrm{NOR} \rightarrow \mathrm{CO}_{2}+\mathrm{H}_{2} \mathrm{O}+\text { intermediate, } \\
& \mathrm{O}_{2} \cdot{ }^{-}+\mathrm{NOR} \rightarrow \mathrm{CO}_{2}+\mathrm{H}_{2} \mathrm{O}+\text { intermediate, } \\
& \cdot \mathrm{OH}+\mathrm{NOR} \rightarrow \mathrm{CO}_{2}+\mathrm{H}_{2} \mathrm{O}+\text { intermediate, } \\
& \text { PS }+ \text { NOR } \rightarrow \text { intermediate, } \\
& \text { Intermediate }+\left(\mathrm{SO}_{4} \cdot^{-}, \cdot \mathrm{OH}, \mathrm{h}^{+} \text {and } \mathrm{O}_{2} \cdot^{-}\right) \rightarrow \mathrm{CO}_{2}+\mathrm{H}_{2} \mathrm{O} \text {, }
\end{aligned}
$$




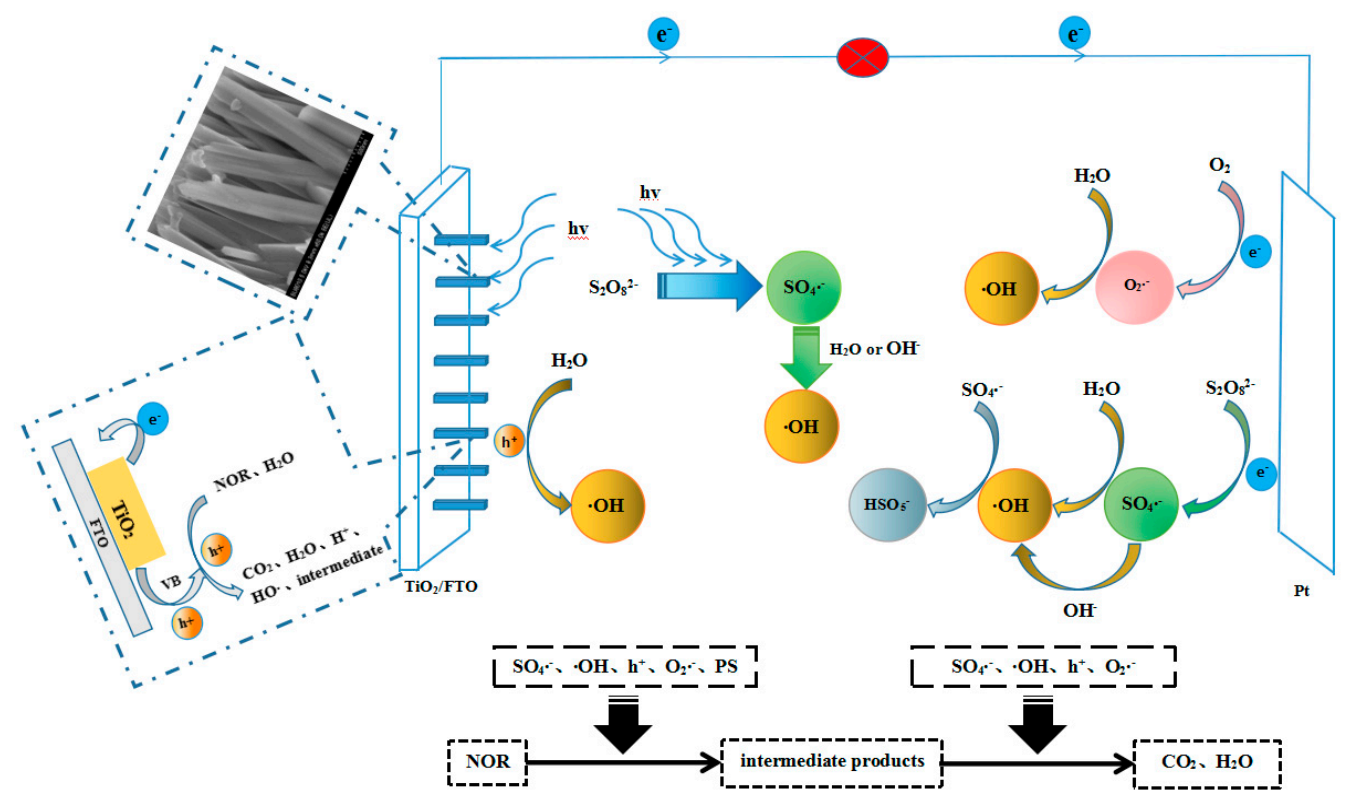

Scheme 1. Schematic illustration of PS activation, radicals' generation, and NOR degradation pathway in PFC/PS system.

\subsection{NOR Degradation and Simultaneous Electricity Generation in Actual Sample}

To examine the practical applicability of the PFC/PS system in real wastewater treatment, the NOR degradation experiment was also conducted in commercial norfloxacin eye-drops sample (Changchun Changqing Pharmaceutical Group Co. Ltd., Changchun, China). Prior to the degradation experiment, the eye-drops sample containing $3 \mathrm{mg} / \mathrm{mL}$ NOR was diluted into that containing $15 \mu \mathrm{g} / \mathrm{mL}$ NOR. Then, $0.1 \mathrm{M} \mathrm{H}_{2} \mathrm{SO}_{4}$ was used to adjust initial $\mathrm{pH}$ of the sample to 3 . After the above pretreatment, the degradation experiment was conducted under optimal condition.

Figure 10 depicts the absorbance spectrum of pretreated eye-drops sample during the degradation process in PFC/PS. As demonstrated in Figure 10, at $0 \mathrm{~min}$, the spectrum presented five absorption peaks at $209 \mathrm{~nm}, 223 \mathrm{~nm}, 277 \mathrm{~nm}, 315 \mathrm{~nm}$, and $330 \mathrm{~nm}$. With increasing the degradation time, the intensities of all absorption peaks decreased gradually. During the degradation process, two additional absorption peaks at $263 \mathrm{~nm}$ and $307 \mathrm{~nm}$ were appeared at different times, which may be attributed to the formation of intermediates. After 60 min degradation, all the absorption peaks had disappeared except the peak at $209 \mathrm{~nm}$, implying that the chemicals in the commercial norfloxacin eye-drops almost were degraded completely. Meanwhile, $0.285 \mathrm{~V}$ of Voc, $0.457 \mathrm{~mA} \cdot \mathrm{cm}^{-2}$ of Jsc, and $0.019 \mathrm{~mW} \cdot \mathrm{cm}^{-2}$ of $\mathrm{P}_{\text {Max }}$ were obtained in the PFC/PS system for the eye-drops sample treatment, as shown in Figure 11. The results established the high efficiency of the proposed PFC/PS system applied in the real wastewater sample. 


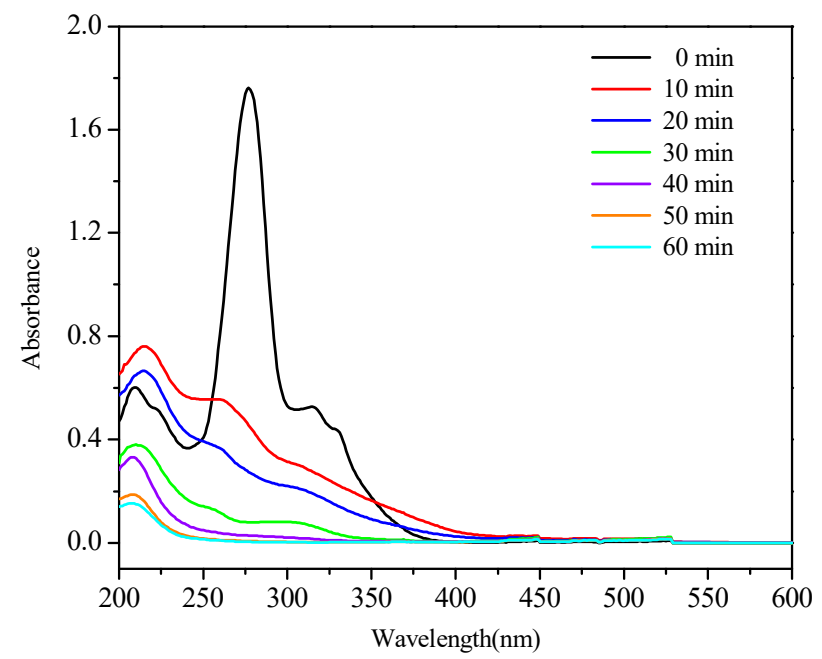

Figure 10. Time course $(0,10,20,30,40,50$, and $60 \mathrm{~min})$ absorbance spectrum of pretreated eye-drops sample during the degradation process in PFC/PS. Experimental conditions: [PS] $=3 \mathrm{mM}, \mathrm{pH}=3$, and electrolyte: $0.1 \mathrm{M} \mathrm{Na}_{2} \mathrm{SO}_{4}$.

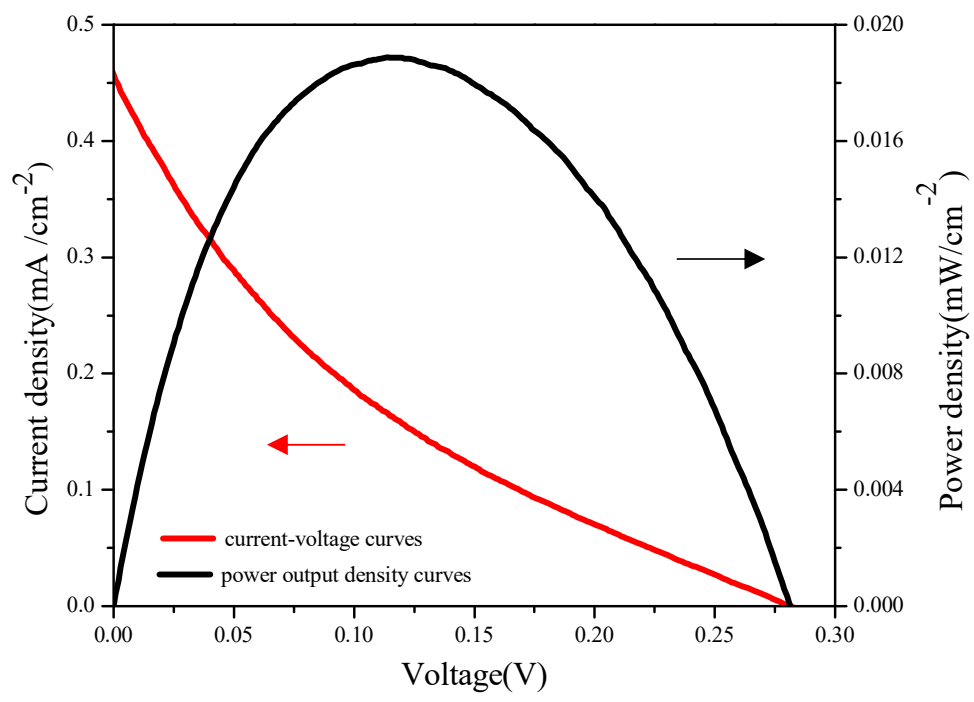

Figure 11. Electricity generation of PFC/PS system for the eye-drops sample treatment. Experimental conditions: $[\mathrm{PS}]=3 \mathrm{mM}, \mathrm{pH}=3$, and electrolyte: $0.1 \mathrm{M} \mathrm{Na}_{2} \mathrm{SO}_{4}$.

\subsection{The Stability of PFC/PS System}

The stability of the PFC/PS system plays an important role in its practical application. As shown in Figure 12, after five times of continuous runs for NOR degradation in PFC/PS system under the optimal conditions, no significant loss was observed for the photocatalytic performance of PFC/PS system. 


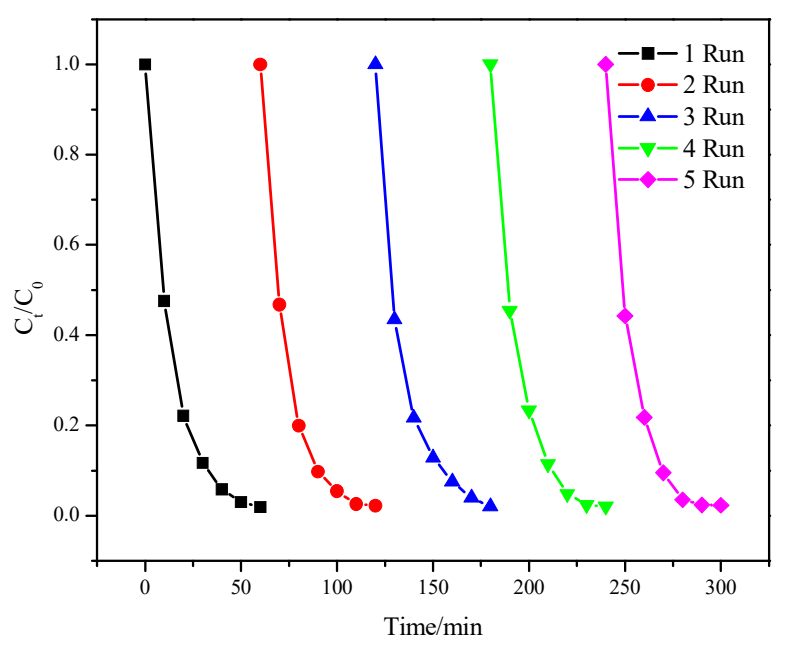

Figure 12. The stability of the PFC/PS system for the degradation of NOR with $10 \mathrm{mg} / \mathrm{L}$ initial concentration under optimal conditions.

\section{Experimental}

\subsection{Materials}

Norfloxacin (NOR, 98.0\%) was purchased from Aladdin Reagent Co. Ltd. (Shanghai, China). Potassium persulfate (PS, $\geq 99.0 \%$ ) was obtained from Sigma-Aldrich (Shanghai, China). Tetra-n-butyl titanate $(\geq 98.5 \%)$, absolute ethyl alcohol ( $\mathrm{EtOH}, \geq 99.7 \%$ ), isopropanol (IPA, $\geq 99.7 \%$ ), sodium sulfate $\left(\mathrm{Na}_{2} \mathrm{SO}_{4}, \geq 99.0 \%\right)$, disodium ethylenediamine tetraacetate (EDTA-2Na, $\geq 99.0 \%$ ), and other reagents were purchased from Tansoole technology Co. Ltd. (Shanghai, China). All the reagents in this work were of analytical grade and used as received without further purification. Deionized water $(18.25 \mathrm{M} \Omega \cdot \mathrm{cm})$ was used throughout this work.

\subsection{Preparation of $\mathrm{TiO}_{2}$ Nanorods}

$\mathrm{TiO}_{2}$ nanorods were prepared using modified hydrothermal method reported previously [53]. FTO conductive glass $\left(10 \times 50 \mathrm{~mm}^{2}, 2.2 \mathrm{~mm}\right.$ thick, $7 \Omega$, Dalian Heptachroma Solar Tech Co. Ltd., Dalian, China) was used as the substrate of the growth of $\mathrm{TiO}_{2}$ nanorods. Prior to use, FTO substrates were dipped into absolute ethyl alcohol for $2 \mathrm{~min}$ to clean off adsorbed dust, followed by thorough ultrasonic degreasing in acetone, isopropanol, and absolute ethyl alcohol in turn for $30 \mathrm{~min}$. Between each step, FTO was rinsed with deionized water $(18.25 \mathrm{M} \Omega \cdot \mathrm{cm})$ and dried with a nitrogen atmosphere for further use. $2 \mathrm{~mL}$ tetra-n-butyl titanate was added into $120 \mathrm{~mL} 6 \mathrm{M} \mathrm{HCl}$. Then, the above solution was treated by magnetic stirring for $5 \mathrm{~min}$ to prepare the precursor solution. After being mixed well, $35 \mathrm{~mL}$ precursor solution was transferred into $50 \mathrm{~mL}$ sealed Teflon-lined stainless-steel autoclave and two pieces of cleaned FTO with the conductive side facing down were inserted into the precursor solution at a diagonal angle. Then, the autoclave was kept at $150{ }^{\circ} \mathrm{C}$ for $12 \mathrm{~h}$. As soon as the hydrothermal reaction was over, the autoclave was quickly cooled under flowing water for $10 \mathrm{~min}$. Then, FTO substrates were taken out and rinsed thoroughly with deionized water. Finally, after being dried with nitrogen gas, the substrates were annealed at $450{ }^{\circ} \mathrm{C}$ for $90 \mathrm{~min}$ in a muffle oven.

\subsection{Characterization of $\mathrm{TiO}_{2}$ Nanorods}

X-ray diffraction (XRD) patterns were performed with a Bruker D2-PHASER X-ray diffractometer (Bruker AXE, Germany) using $\mathrm{Cu} \mathrm{K}-\alpha$ radiation from $5^{\circ}$ to $90^{\circ}$ at a scanning speed of $0.2^{\circ} \mathrm{S}^{-1}$. The obtained XRD patterns were analyzed by MDI Jade 6.0 software. The scanning electron microscopic (SEM) images were recorded by a Hitachi SU8010 instrument (Hitachi, Japan). 


\subsection{NOR Degradation Experiments}

The degradation experiments of NOR solutions were carried out in a glass reaction cell equipped with a quartz window. The total volume of the NOR solutions was $80 \mathrm{~mL}$. Unless otherwise stated, $0.1 \mathrm{M} \mathrm{Na}_{2} \mathrm{SO}_{4}$ was chosen as a supporting electrolyte and added into the NOR solution throughout all the experiments. The initial $\mathrm{pH}$ and concentration of NOR solution as well as the concentration of PS used in the degradation experiments were adjusted to desired value. During the degradation process, the NOR solution was under continuous and moderate stirring. In addition, no external potential was applied.

PFC and PFC/PS system were both assembled using a conventional three-electrode configuration with a saturated calomel electrode (SCE) as the reference electrode, a platinum wire as the auxiliary electrode, and the as-prepared $\mathrm{TiO}_{2} / \mathrm{FTO}$ electrode as the working electrode, respectively. The $\mathrm{TiO}_{2} / \mathrm{FTO}$ electrode with a fixed exposed area of $2 \mathrm{~cm}^{2}$ was carefully placed at the quartz window of the glass reaction cell to ensure the UV light illumination. In order to efficiently activate PS and excite $\mathrm{TiO}_{2}$, a 15-W mercury lamp (Cnlight Co., Ltd., Guangdong, China) with $254 \mathrm{~nm}$ major emission wavelength was placed outside the quartz window and served as UV light source. During the working time, the distance between the UV light and $\mathrm{TiO}_{2} / \mathrm{FTO}$ electrode was fixed of $10 \mathrm{~cm}$. The UV irradiation intensity of UV light on the surface of $\mathrm{TiO}_{2} / \mathrm{FTO}$ electrode is $61 \mu \mathrm{W} \mathrm{cm} \mathrm{cm}^{-2}$ determined with a UV radiometer (Photoelectric Instrument Factory of Beijing Normal University, Beijing, China). The PS system was assembled in the same way, except without a three-electrode system.

During the degradation process, the samples at given intervals were taken from the reaction solution and measured at $277 \mathrm{~nm}$ (the maximum ultraviolet-visible (UV-vis) absorption wavelength of NOR) using UV-vis spectroscopy. The degradation efficiency could be calculated according to Equation (22):

$$
\text { Degradation efficiency } \%=\left(C_{0}-C_{t}\right) / C_{0} \times 100 \%,
$$

where $C_{0}$ and $C_{t}$ refer to the concentration of NOR at the initial and at the sampling time $t$, respectively.

The current-voltage (I-V) curves of the PFC system and PFC/PS system were recorded using CHI660E electrochemical workstation (Shanghai Chenhua Instrument Co. Ltd., Shanghai, China). The linear sweep voltammetry (LSV) with a scan rate of $5 \mathrm{mV} \cdot \mathrm{S}^{-1}$ was used as testing technique. The power output density $(\mathrm{P}-\mathrm{V})$ curves were obtained by plotting the power density $(\mathrm{V} \times \mathrm{I} / \mathrm{A})$ versus the voltage $(\mathrm{V})$, where A represents the geometric area of $\mathrm{TiO}_{2} / \mathrm{FTO}$ electrode.

TOC changes of the NOR samples under the optimal degradation conditions in PFC/PS system were recorded using a vario TOC analyzer (Elementar, Langenselbold, Germany). Moreover, the TOC removal efficiency could also be calculated by Equation (1). At this point, $C_{0}$ and $C_{t}$ in Equation (1) represent the TOC concentration of NOR solution at initial and at the sampling time $t$, respectively.

All the UV-vis data in this work were obtained by using a L9 UV-vis Spectrophotometer (INESA Scientific Instrument Co. Ltd., Shanghai, China). The UV-vis absorption spectra were collected by UVwin8 software.

All the experiments were repeated at least three times to check their reproducibility.

\section{Conclusions}

In this work, a synergistic PFC/PS system was successfully established by adding PS into the PFC system. SEM and XRD analyses confirmed that the prepared photoanode contained $\mathrm{TiO}_{2}$ nanorods with a $3 \mu \mathrm{m}$ length and a $200 \mathrm{~nm}$ edge length of square top facets. In the coupling PFC/PS system, the electricity generation was nearly doubled compared to the conventional PFC system. Moreover, the NOR degradation reached $98.10 \%$ and the corresponding apparent rate constant was $6.69 \times 10^{-2} \mathrm{~min}^{-1}$ after 60 min operation in PFC/PS system. At an initial solution $\mathrm{pH}$ of 3.0, NOR degraded with the fastest rate. Furthermore, the higher concentration of PS and lower concentration of NOR resulted in a higher degradation efficiency of NOR in the PFC/PS system. Moreover, the radical trapping experiments demonstrated that $\mathrm{SO}_{4} \cdot{ }^{-}$was the most dominant radical, while $\cdot \mathrm{OH}$ was the second most 
dominant radical. $\mathrm{O}_{2} \cdot{ }^{-}$and $\mathrm{h}^{+}$also played a relatively minor role in the NOR degradation. A tentative function mechanism was proposed according to the analyses of radical trapping experiments results. The TOC removal indicated the high mineralization though existing hysteresis. Additionally, the successful degradation and electricity generation in the commercial NOR eye-drops sample suggested that the proposed PFC/PS system is promising to simultaneously be applied in real wastewater for organic matter degradation and electricity generation.

Author Contributions: Data curation, J.L. and L.Z;; Formal analysis, J.L.; Funding acquisition, R.L. and X.L.; Investigation, J.L. and L.Z.; Project administration, R.L.; Supervision, R.L.; Writing-original draft, J.L.; Writing—review and editing, R.L.

Funding: This research was founded by the National Natural Science Foundation of China (Grant No. 61601313); Science and Technology Innovation Cultivation Project Foundation of Science and Technology Agency of Sichuan Province (Grant No. 2017094) (Both for RZ); the Innovation Fund of Postgraduate, Sichuan University of Science \& Engineering (Grant No. B20306180 for JW); and the Scientific Research and Innovation Team Project Foundation of Education Department of Sichuan Province (Grant No.17TD0025 for XY).

Conflicts of Interest: The authors declare no conflict of interest.

\section{References}

1. Zhang, A.Y.; Wang, W.; Chen, J.J.; Liu, C.; Zhang, X.; Li, W.W.; Si, Y.; Yu, H.Q. Epitaxial facet junction on $\mathrm{TiO}_{2}$ single crystals for efficient photocatalytic water splitting. Energy Environ. Sci. 2018, 11, 1444-1448. [CrossRef]

2. Taraka, T.P.Y.; Gautam, A.; Jain, S.L.; Bojja, S.; Pal, U. Controlled addition of $\mathrm{Cu} / \mathrm{Zn}$ in hierarchical $\mathrm{CuO} / \mathrm{ZnO}$ p-n heterojunction photocatalyst for high photoreduction of $\mathrm{CO} 2$ to MeOH. J. $\mathrm{CO}_{2}$ Util. 2019, 31, 207-214. [CrossRef]

3. Cardoso, J.; Stulp, S.; De Brito, J.; Flor, J.; Frem, R.; Zanoni, M. MOFs based on ZIF-8 deposited on TiO2 nanotubes increase the surface adsorption of $\mathrm{CO}_{2}$ and its photoelectrocatalytic reduction to alcohols in aqueous media. Appl. Catal. B Environ. 2018, 225, 563-573. [CrossRef]

4. Kaneco, S.; Shimizu, Y.; Ohta, K.; Mizuno, T. Photocatalytic reduction of high pressure carbon dioxide using $\mathrm{TiO} 2$ powders with a positive hole scavenger. J. Photochem. Photobiol. A Chem. 1998, 115, 223-226. [CrossRef]

5. Urbain, F.; Murcia-López, S.; Nembhard, N.; Vázquez-Galván, J.; Flox, C.; Smirnov, V.; Welter, K.; Andreu, T.; Finger, F; Morante, J.R. Solar vanadium redox-flow battery powered by thin-film silicon photovoltaics for efficient photoelectrochemical energy storage. J. Phys. D Appl. Phys. 2019, 52, 044001. [CrossRef]

6. Heidrich, E.S.; Curtis, T.P.; Dolfing, J.; Curtis, T. Determination of the Internal Chemical Energy of Wastewater. Environ. Sci. Technol. 2011, 45, 827-832. [CrossRef] [PubMed]

7. Zhang, Q.; Li, Y.; Yang, Q.; Chen, H.; Chen, X.; Jiao, T.; Peng, Q. Distinguished Cr(VI) capture with rapid and superior capability using polydopamine microsphere: Behavior and mechanism. J. Hazard. Mater. 2018, 342, 732-740. [CrossRef]

8. Pan, Y.; Wang, Y.; Zhou, A.; Wang, A.; Wu, Z.; Lv, L.; Li, X.; Zhang, K.; Zhu, T. Removal of azo dye in an up-flow membrane-less bioelectrochemical system integrated with bio-contact oxidation reactor. Chem. Eng. J. 2017, 326, 454-461. [CrossRef]

9. Ter Heijne, A.; Strik, D.P.B.T.B.; Hamelers, H.V.M.; Buisman, C.J.N. Cathode Potential and Mass Transfer Determine Performance of Oxygen Reducing Biocathodes in Microbial Fuel Cells. Environ. Sci. Technol. 2010, 44, 7151-7156. [CrossRef]

10. Xia, L.; Bai, J.; Li, J.; Zeng, Q.; Li, X.; Zhou, B. A highly efficient BiVO 4/WO $3 /$ W heterojunction photoanode for visible-light responsive dual photoelectrode photocatalytic fuel cell. Appl. Catal. B Environ. 2016, 183, 224-230. [CrossRef]

11. Kan, L.; Yunlan, X.; Yi, H.; Chen, Y.; Yalin, W.; Jinping, J. Photocatalytic fuel cell (PFC) and dye self-photosensitization photocatalytic fuel cell (DSPFC) with BiOCl/Ti photoanode under UV and visible light irradiation. Environ. Sci. Technol. 2013, 47, 3490-3497.

12. Wang, B.; Zhang, H.; Lu, X.-Y.; Xuan, J.; Leung, M.K. Solar photocatalytic fuel cell using CdS-TiO2 photoanode and air-breathing cathode for wastewater treatment and simultaneous electricity production. Chem. Eng. J. 2014, 253, 174-182. [CrossRef] 
13. Li, J.; Li, J.; Chen, Q.; Bai, J.; Zhou, B. Converting hazardous organics into clean energy using a solar responsive dual photoelectrode photocatalytic fuel cell. J. Hazard. Mater. 2013, 262, 304-310. [CrossRef] [PubMed]

14. Shi, H.; Wu, Z.; Zhao, G.; Zhang, Y.; Liu, J. A solar-driven photocatalytic fuel cell with dual photoelectrode for simultaneous wastewater treatment and hydrogen production. J. Mater. Chem. A 2015, 3, 3416-3424.

15. Chen, Q.; Li, J.; Li, X.; Huang, K.; Zhou, B.; Cai, W.; Shangguan, W. Visible-Light Responsive Photocatalytic Fuel Cell Based on WO3/W Photoanode and $\mathrm{Cu}_{2} \mathrm{O} / \mathrm{Cu}$ Photocathode for Simultaneous Wastewater Treatment and Electricity Generation. Environ. Sci. Technol. 2012, 46, 11451-11458. [CrossRef] [PubMed]

16. Zarei, E.; Ojani, R. Fundamentals and some applications of photoelectrocatalysis and effective factors on its efficiency: A review. J. Solid State Electrochem. 2017, 12, 305-336. [CrossRef]

17. Zhao, K.; Zeng, Q.; Bai, J.; Li, J.; Xia, L.; Chen, S.; Zhou, B. Enhanced organic pollutants degradation and electricity production simultaneously via strengthening the radicals reaction in a novel Fenton-photocatalytic fuel cell system. Water Res. 2017, 108, 293-300. [CrossRef]

18. Lee, C.; Kim, H.-H.; Park, N.B. Chemistry of persulfates for the oxidation of organic contaminants in water. Membr. Water Treat. 2018, 9, 405-419.

19. Yang, S.; Wang, P.; Yang, X.; Wei, G.; Zhang, W.; Shan, L. A novel advanced oxidation process to degrade organic pollutants in wastewater: Microwave-activated persulfate oxidation. J. Environ. Sci. 2009, 21, 1175-1180. [CrossRef]

20. Tang, S.; Yuan, D.; Rao, Y.; Na, L.; Qi, J.; Cheng, T.; Sun, Z.; Gu, J.; Huang, H. Persulfate activation in gas phase surface discharge plasma for synergetic removal of antibiotic in water. Chem. Eng. J. 2017, 337, $446-454$. [CrossRef]

21. Zhou, Y.; Zhu, N.; Guo, W.; Wang, Y.; Huang, X.; Wu, P.; Dang, Z.; Zhang, X.; Xian, J. Simultaneous electricity production and antibiotics removal by microbial fuel cells. J. Environ. Manag. 2018, 217, 565-572. [CrossRef] [PubMed]

22. Yang, L.-H.; Ying, G.-G.; Su, H.-C.; Stauber, J.L.; Adams, M.S.; Binet, M.T. Growth-inhibiting effects of 12 antibacterial agents and their mixtures on the freshwater microalga Pseudokirchneriella subcapitata. Environ. Toxicol. Chem. 2008, 27, 1201-1208. [CrossRef] [PubMed]

23. Chen, J.; Jin, M.; Qiu, Z.-G.; Guo, C.; Chen, Z.-L.; Shen, Z.-Q.; Wang, X.-W.; Li, J.-W. A survey of drug resistance bla genes originating from synthetic plasmid vectors in six chinese rivers. Environ. Sci. Technol. 2012, 46, 13448-13454. [CrossRef] [PubMed]

24. Sayed, M.; Shah, L.A.; Khan, J.A.; Shah, N.S.; Nisar, J.; Khan, H.M.; Zhang, P.; Khan, A.R. Efficient photocatalytic degradation of norfloxacin in aqueous media by hydrothermally synthesized immobilized $\mathrm{TiO}_{2} / \mathrm{Ti}$ films with exposed $\{001\}$ facets. J. Phys. Chem. A 2016, 120, 9916-9931. [CrossRef] [PubMed]

25. Chen, L.; Ding, D.; Liu, C.; Cai, H.; Qu, Y.; Yang, S.; Gao, Y.; Cai, T. Degradation of norfloxacin by $\mathrm{CoFe}_{2} \mathrm{O}_{4}$-GO composite coupled with peroxymonosulfate: A comparative study and mechanistic consideration. Chem. Eng. J. 2018, 334, 273-284. [CrossRef]

26. Kim, K.J.; Benkstein, K.D.; Lagemaat, J.V.D.; Frank, A.J. Characteristics of low-temperature annealed $\mathrm{TiO}_{2}$ films deposited by precipitation from hydrolyzed $\mathrm{TiCl}_{4}$ solutions. Chem. Mater. 2002, 14, 1042-1047. [CrossRef]

27. Park, N.G.; Lagemaat, J.V.D.; Frank, A.J. Comparison of Dye-Sensitized Rutile- and Anatase-Based $\mathrm{TiO}_{2}$ Solar Cells. J. Phys. Chem. B 2000, 104, 8989-8994. [CrossRef]

28. Ohno, T.; Tokieda, K.; Higashida, S.; Matsumura, M. Synergism between rutile and anatase $\mathrm{TiO}_{2}$ particles in photocatalytic oxidation of naphthalene. Appl. Catal. A Gen. 2003, 224, 383-391. [CrossRef]

29. Chenju, L.; Guo, Y. Mass transfer and chemical oxidation of naphthalene particles with zerovalent iron activated persulfate. Environ. Sci. Technol. 2010, 44, 8203-8208.

30. Khalik, W.F.; Ho, L.-N.; Ong, S.-A.; Voon, C.-H.; Wong, Y.-S.; Yusoff, N.; Lee, S.-L.; Yusuf, S.Y. Optimization of degradation of Reactive Black 5 (RB5) and electricity generation in solar photocatalytic fuel cell system. Chemosphere 2017, 184, 112-119. [CrossRef]

31. Cai, T.; Liu, Y.; Wang, L.; Zhang, S.; Zeng, Y.; Yuan, J.; Ma, J.; Dong, W.; Liu, C.; Luo, S. Silver phosphate-based Z-Scheme photocatalytic system with superior sunlight photocatalytic activities and anti-photocorrosion performance. Appl. Catal. B Environ. 2017, 208,1-13. [CrossRef]

32. Yi, L.Q.; Yi, F.Z.; Hao, Y.Y.; Xu, C.S. Enhanced visible light photocatalytic activity of AgBr on $\{001\}$ facets exposed to BiOCl. J. Alloys Compd. 2017, 712, 535-542. 
33. Wang, K.; Pang, J.; Li, L.; Zhou, S.; Li, Y.; Zhang, T. Synthesis of hydrophobic carbon nanotubes/reduced graphene oxide composite films by flash light irradiation. Front. Chem. Sci. Eng. 2018, 12, 376-382. [CrossRef]

34. Liu, J.; Li, Y.; Ke, J.; Wang, S.; Wang, L.; Xiao, H. Black NiO-TiO 2 nanorods for solar photocatalysis: Recognition of electronic structure and reaction mechanism. Appl. Catal. B Environ. 2018, 224, 705-714. [CrossRef]

35. Zhao, Q.; Li, Z.; Deng, Q.; Zhu, L.; Luo, S.; Li, H. Paired photoelectrocatalytic reactions of glucose driven by a photoelectrochemical fuel cell with assistance of methylene blue. Electrochim. Acta 2016, 210, 38-44. [CrossRef]

36. Zeng, H.; Liu, S.; Chai, B.; Cao, D.; Wang, Y.; Zhao, X. Enhanced Photoelectrocatalytic Decomplexation of Cu-EDTA and Cu Recovery by Persulfate Activated by UV and Cathodic Reduction. Environ. Sci. Technol. 2016, 50, 6459-6466. [CrossRef] [PubMed]

37. Ke, J.; Liu, J.; Sun, H.; Zhang, H.; Duan, X.; Liang, P.; Li, X.; Tade, M.O.; Liu, S.; Wang, S. Facile assembly of $\mathrm{Bi}_{2} \mathrm{O}_{3} \mathrm{Bi}_{2} \mathrm{~S}_{3} / \mathrm{MoS}_{2}$ n-p heterojunction with layered $\mathrm{n}-\mathrm{Bi}_{2} \mathrm{O}_{3}$ and $\mathrm{p}-\mathrm{MoS}_{2}$ for enhanced photocatalytic water oxidation and pollutant degradation. Appl. Catal. B Environ. 2017, 200,47-55. [CrossRef]

38. Li, N.; Tang, S.; Rao, Y.; Qi, J.; Zhang, Q.; Yuan, D. Peroxymonosulfate enhanced antibiotic removal and synchronous electricity generation in a photocatalytic fuel cell. Electrochim. Acta 2019, 298, 59-69. [CrossRef]

39. Li, N.; Tang, S.; Rao, Y.; Qi, J.; Wang, P.; Jiang, Y.; Huang, H.; Gu, J.; Yuan, D. Improved dye removal and simultaneous electricity production in a photocatalytic fuel cell coupling with persulfate activation. Electrochim. Acta 2018, 270, 330-338. [CrossRef]

40. Lau, T.K.; Chu, W.; Graham, N.J.D. The Aqueous Degradation of Butylated Hydroxyanisole by UV/S2O82-: Study of Reaction Mechanisms via Dimerization and Mineralization. Environ. Sci. Technol. 2007, 41, 613-619. [CrossRef]

41. Wu, Y.; Zhu, X.; Chen, H.; Dong, W.; Zhao, J. Photodegradation of 4-tert-butylphenol in aqueous solution by UV-C, UV/ $\mathrm{H}_{2} \mathrm{O}_{2}$ and $\mathrm{UV} / \mathrm{S}_{2} \mathrm{O}_{2}{ }^{-}$system. J. Environ. Sci. Health Part A 2016, 51, 440-445. [CrossRef] [PubMed]

42. Liang, C.; Lai, M.-C. Trichloroethylene Degradation by Zero Valent Iron Activated Persulfate Oxidation. Environ. Eng. Sci. 2008, 25, 1071-1078. [CrossRef]

43. Liang, C.; Bruell, C.J.; Albert, M.F.; Paul, E.; Ryan, D.K. Evaluation of reverse osmosis and nanofiltration for in situ persulfate remediated groundwater. Desalination 2007, 208, 238-259. [CrossRef]

44. Kermani, M.; Mohammadi, F.; Kakavandi, B.; Esrafili, A.; Rostamifasih, Z. Simultaneous catalytic degradation of 2,4-D and MCPA herbicides using sulfate radical-based heterogeneous oxidation over persulfate activated by natural hematite $\left(\alpha-\mathrm{Fe}_{2} \mathrm{O}_{3} / \mathrm{PS}\right)$. J. Phys. Chem. Solids 2018, 117, 49-59. [CrossRef]

45. Weng, C.H.; Tsai, K.L. Ultrasound and heat enhanced persulfate oxidation activated with $\mathrm{Fe}^{0}$ aggregate for the decolorization of C.I. Direct Red 23. Ultrason. Sonochem. 2016, 29, 11-18. [CrossRef] [PubMed]

46. Ke, Q.; Shi, Y.; Liu, Y.; Chen, F.; Wang, H.; Wu, X.-L.; Lin, H.; Chen, J. Enhanced catalytic degradation of bisphenol A by hemin-MOFs supported on boron nitride via the photo-assisted heterogeneous activation of persulfate. Sep. Purif. Technol. 2019, 229, 115822. [CrossRef]

47. Jiang, Y.R.; Chou, S.Y.; Chang, J.L.; Huang, S.T.; Lin, H.P.; Chen, C.C. Hydrothermal synthesis of bismuth oxybromide-bismuth oxyiodide composites with highly visible light photocatalytic performance for the degradation of CV and phenol. Rsc Adv. 2015, 5, 30851-30860. [CrossRef]

48. Song, W.; Ge, P.; Ke, Q.; Sun, Y.; Chen, F.; Wang, H.; Shi, Y.; Wu, X.-L.; Lin, H.; Chen, J.; et al. Insight into the mechanisms for hexavalent chromium reduction and sulfisoxazole degradation catalyzed by graphitic carbon nitride: The Yin and Yang in the photo-assisted processes. Chemosphere 2019, 221, 166-174. [CrossRef] [PubMed]

49. Wang, X.; Sun, Y.; Yang, L.; Shang, Q.; Wang, D.; Guo, T.; Guo, Y. Novel photocatalytic system Fe-complex/TiO 2 for efficient degradation of phenol and norfloxacin in water. Sci. Total Environ. 2019, 656, 1010-1020. [CrossRef] [PubMed]

50. Ghauch, A.; Tuqan, A.M.; Kibbi, N. Naproxen abatement by thermally activated persulfate in aqueous systems. Chem. Eng. J. 2015, 279, 861-873. [CrossRef]

51. Tang, S.; Xue, L.I.; Zhang, C.; Liu, Y.; Zhang, W.; Yuan, D. Strengthening decomposition of oxytetracycline in DBD plasma coupling with Fe-Mn oxide-loaded granular activated carbon. Engl. Ed. Plasma Sci. Technol. 2019, 21, 86-92. [CrossRef] 
52. Ding, D.; Liu, C.; Ji, Y.; Yang, Q.; Chen, L.; Jiang, C.; Cai, T. Mechanism insight of degradation of norfloxacin by magnetite nanoparticles activated persulfate: Identification of radicals and degradation pathway. Chem. Eng. J. 2017, 308, 330-339. [CrossRef]

53. Bin, L.; Aydil, E.S. Growth of oriented single-crystalline rutile $\mathrm{TiO}_{2}$ nanorods on transparent conducting substrates for dye-sensitized solar cells. J. Am. Chem. Soc. 2009, 131, 3985-3990. 